\title{
WETENSCHAP
}

\section{Verscherpt Kader goed bestuur in de zorg: schoenmaker(s), blijf bij je leest!}

\author{
W.J. Oostwouder
}

\section{Inleiding}

Op 3 juli 2020 publiceerden de Inspectie Gezondheidszorg en Jeugd (IGJ) en de Nederlandse Zorgautoriteit (NZa) het nieuwe 'Kader goed bestuur'. Zij merken op dat dit kader over bestuur en toezicht bij zorginstellingen een aanscherping is van de versie uit juli 2016: 'Het verschil tussen het kader 2016 en 2020 zijn de wijzigingen in het thema intern toezicht. De verwachting is dat ook wet- en regelgeving over dit onderwerp de komende jaren gaat veranderen.'

Deze verwachting is geheel gewettigd voor zover het de Wet toetreding zorgaanbieders (Wtza) en de Aanpassingswet toetreding zorgaanbieders (Awtza) betreft en bijna gewettigd voor zover dit het (concept-)Besluit houdende regels ter uitvoering van de Wtza (Uitvoeringsbesluit Wtza) en het wetsvoorstel Wet bestuur en toezicht rechtspersonen (WBTR) betreft.

De Wtza is op 9 juni 2020 als hamerstuk door de Eerste Kamer aangenomen. Het is de bedoeling dat deze wet op 1 juli 2021 in werking treedt. De internetconsultatie van het (concept-)Uitvoeringsbesluit Wtza is op 21 juli 2020 afgerond. De Tweede Kamer heeft op 28 januari 2020 het WBTR aangenomen. De Eerste Kamercommissie voor Justitie en Veiligheid (JenV) heeft op 31 maart 2020 het voorlopig verslag uitgebracht en wacht op de memorie van antwoord.

Je zou ervan uit mogen gaan dat de IGJ en NZa kennis hebben genomen van deze voorgenomen regelgeving en hun aangescherpte kader hiermee in ieder geval niet strijdig is.

Hierna bespreek ik de belangrijkste wijzigingen voor de interne toezichthouder (hierna ook: raad van commissarissen of $\mathrm{RvC}$ en raad van toezicht of RvT) van een zorginstelling in respectievelijk het WBTR, de Wtza en het (concept-)Uitvoeringsbesluit Wtza. Vervolgens ga ik na of deze wijzigingen passen bij hetgeen de IGJ en de NZa blijkens het nieuwe 'Kader goed bestuur' van de interne toezichthouder verwachten. Ten slotte beantwoord ik de vraag of uitvoering van deze verwachtingen in de praktijk leidt tot wenselijke resultaten. 


\section{Het wetsvoorstel Wet bestuur en toezicht rechtspersonen}

In het WBTR wordt voorzien in een wettelijke grondslag voor raden van commissarissen (RvC's) bij alle in Boek 2 van het Burgerlijk Wetboek (BW) geregelde rechtspersonen. Het RvC-begrip en de daarbij behorende regelingen in Boek $2 \mathrm{BW}$ zullen na invoering van dit wetsvoorstel niet alleen voor naamloze en besloten vennootschappen (nv's en bv's), maar ook voor de stichting (de rechtsvorm van de meeste zorginstellingen), vereniging, coöperatie en onderlinge waarborgmaatschappij wettelijk zijn vastgelegd. Deze regelingen bevatten de kerntaak, normstelling en bevoegdheden van de interne toezichthouder. Van Uchelen-Schipper merkt daarbij terecht op dat de bevoegdheid om de bestuurders te schorsen een belangrijke wettelijke bevoegdheid is van de $\mathrm{RvC} / \mathrm{RvT}^{1}$

Indien een orgaan voldoet aan het RvC-begrip (een bij de statuten ingesteld orgaan waaraan de taak is opgedragen om toezicht te houden op het bestuur en de algemene gang van zaken van de rechtspersoon en de daaraan verbonden onderneming of organisatie ${ }^{2}$ ) zal de wettelijke $\mathrm{RvC}$-regeling van toepassing zijn. Het maakt daarbij niet uit hoe dit orgaan genoemd wordt: raad van commissarissen, raad van toezicht, raad van advies of een andere naam. De leden van dit orgaan moeten zich (net als de statutaire bestuurders bij Boek 2 BW-rechtspersonen) richten op het belang van de rechtspersoon en de daaraan verbonden onderneming of organisatie. Dit wordt dus ook voor zorginstellingen met de stichtingsvorm het wettelijk richtsnoer.

Houwen $^{3}$ merkt op dat van overheidswege wordt uitgedragen dat bestuurders en interne toezichthouders in het semipublieke domein 'primair het publieke belang en de dienstverlening aan de burger dienen, en niet het belang van de instelling' . Hij wijst voorts op de andersluidende opvatting in de literatuur ${ }^{5}$ dat bestuur en

1 M.J. van Uchelen-Schipper, Het Wetsvoorstel bestuur en toezicht rechtspersonen in relatie tot sectorale regels en governancecodes voor stichtingen, MvO 2019, afl. 3-4, p. 72.

2 A.G.H. Klaassen, Van zorginstellingen, zorgverzekeraars en patiëntenverenigingen en het wetsvoorstel Wet bestuur en toezicht rechtspersonen, O\&F 2017, afl. 1, p. 21 merkt onder verwijzing naar de MvT WBTR, Kamerstukken II 2015/16, 34491, nr. 3, p. 20-21, op dat dit betekent dat een orgaan dat enkel tot taak heeft om het bestuur te adviseren binnen de rechtspersoon geen $\mathrm{RvC}$ is in de zin van Boek 2 BW. Mijns inziens moet aandacht worden besteed aan het gevaar van de glijdende schaal, waarbij een Raad van Advies zich steeds meer gaat opstellen als een RvC. Ik acht het niet denkbeeldig dat een dergelijk orgaan met de naam 'Raad van Advies' door de rechter zal worden gekwalificeerd als een $\mathrm{RvC}$, met alle aansprakelijkheidsgevolgen van dien.

3 L.G.H. Houwen, De WBTR in het semipublieke domein: verhouding Boek 2 BW en sectorale governanceregulering, TvOB 2016, afl. 1, p. 24.

4 Kamerstukken II 2014/15, 33822 (Financieel beheer en toezicht semipublieke sector), nr. 4 (Brief van de Minister van Economische Zaken d.d. 2 november 2014), p. 8.

5 Houwen 2016, p. 24 noemt daarbij de volgende literatuur: 'H. Hoek, "Gezondheidszorg dient geen publiek belang”, in: Zorg voor Toezicht, De maatschappelijke betekenis van governance in de zorg, Amsterdam: Mediawerf 2015, p. 154-162; vgl. ook C.H.C. Overes, "Worstelen met governance van semipublieke instellingen en pensioenfondsen”, WPNR 2013, afl. 6996, p. 1043-1044; en Reactie Zuidas Instituut voor Financieel recht en Ondernemingsrecht (ZIFO), Reactie consultatie voorontwerp Bestuur en toezicht rechtspersonen d.d. 6 mei 2014, p. 519.' 
intern toezicht zich niet (primair) zouden moeten richten op maatschappelijke of publieke belangen.

Evenals Houwen ${ }^{6}$ kies ik voor een synthese van deze opvattingen. Duidelijk is dat privaatrechtelijke instellingen met een semipublieke doelstelling niet (primair) verantwoordelijk zijn voor de behartiging van de publieke belangen van de overheid. Maar via die doelstelling wordt wel duidelijk dat de rechtspersoon zich mede richt op de verwezenlijking van het door hem te behartigen publieke deelbelang. Hiermee wordt dit deelbelang onderdeel van het belangenspectrum dat bestuurders van zorginstellingen en andere semipublieke instellingen moeten betrekken bij de afweging of bepaalde besluiten en/of handelingen in het belang van de semipublieke instelling en de daaraan verbonden onderneming of organisatie zijn.

Houwen ${ }^{7}$ constateert dat het (inmiddels vorige) kabinet de visie dat het publieke belang een onderdeel is van het meeromvattende belang van de rechtspersoon onderschreef: 'Binnen dit samenstel van belangen heeft "dit publieke belang een prominente plaats", maar is "niet op voorhand doorslaggevend binnen het geheel van deelbelangen dat samen het belang van de rechtspersoon vormt". 8

Eerder had de wetgever al benadrukt dat de raad van toezicht (van een woningcorporatie) niet de taak heeft om 'zich te richten op de behartiging van publieke belangen die de overheid zich stelt. Deze moeten een publiekrechtelijke grondslag hebben en langs publiekrechtelijke wijze worden verzekerd.'

Bij alle Boek 2 BW-rechtspersonen (dus ook voor de stichting) wordt een wettelijke basis gecreëerd voor de zogenoemde 'one tier board'. Hierbij nemen toezichthoudende en uitvoerende bestuurders in één bestuur zitting.

Voorts wordt voor stichtingen en verenigingen een wettelijke tegenstrijdigbelangregeling ingevoerd, die gebaseerd is op de wettelijke tegenstrijdigbelangregeling voor de nv's en bv's. Deze regeling bepaalt dat zowel een bestuurder als een commissaris niet aan de beraadslaging en de besluitvorming mag deelnemen indien betrokkene een tegenstrijdig belang heeft met de rechtspersoon. Indien alle bestuurders een tegenstrijdig belang hebben, dan dient het bestuursbesluit genomen te worden door de $\mathrm{RvC}$. Hebben alle commissarissen een tegenstrijdig belang, dan moet bij de nv, de bv, de vereniging, de coöperatie of de onderlinge waarborgmaatschappij - tenzij de statuten anders bepalen - het besluit worden genomen door de algemene vergadering. De stichting heeft geen aandeelhouders en geen leden en derhalve ook geen algemene vergadering. Daarom geldt voor de

$6 \quad$ Houwen 2016, p. 24.

7 Houwen 2016, p. 24.

8 Houwen 2016, p. 24 haalt hier de belangrijkste delen aan van Kamerstukken II 2014/15, 34251 (Wet versterking bestuurskracht onderwijsinstellingen), nr. 4 (advies Afdeling advisering Raad van State en nader rapport), p. 1-8 en 13-14.

9 Kamerstukken II 2010/11, 32769 (Herzieningswet toegelaten instellingen volkshuisvesting), nr. 3, p. 42 (MvT). 
stichting op dit punt een enigszins andere regeling voor het geval dat er geen $\mathrm{RvC}$ is of alle commissarissen een tegenstrijdig belang hebben. Dan neemt het bestuur als alle bestuurders een tegenstrijdig belang hebben toch het besluit, maar moeten de overwegingen die aan het besluit ten grondslag liggen, schriftelijk worden vastgelegd, tenzij de statuten anders bepalen.

Indien het een besluit betreft dat primair door de $\mathrm{RvC}$ genomen moet worden, maar alle commissarissen geconflicteerd zijn, neemt de $\mathrm{RvC}$ toch het besluit, maar weer met voornoemde vastleggingsverplichting, tenzij de statuten anders bepalen.

Bestuurders en commissarissen moeten zich alleen terugtrekken uit de beraadslaging en besluitvorming bij een (daadwerkelijk) 'direct of indirect persoonlijk' tegenstrijdig belang ${ }^{10}$.

Daarnaast worden in het wetsvoorstel de aansprakelijkheidsregels voor bestuurders en commissarissen van verenigingen en stichtingen verscherpt. Zo wordt art. 2:9 BW (dat de interne aansprakelijkheid regelt) ook van toepassing op commissarissen bij verenigingen en stichtingen en wordt de faillissementsaansprakelijkheid (die nu al in art. 2:138 en 2:248 BW voor bestuurders en commissarissen van nv's en bv's geregeld is) ook van toepassing op bestuurders en commissarissen van verenigingen en stichtingen. Op onderdelen van deze regeling wordt overigens wel een uitzondering gemaakt voor bestuurders en commissarissen van verenigingen en stichtingen die niet vennootschapsbelastingplichtig zijn en niet op basis van sectorale wet- en regelgeving ${ }^{11}$ een financiële verantwoording hoeven te publiceren die gelijk of gelijkwaardig is aan een jaarrekening.

Tegenover deze bestuurders en commissarissen geldt dan niet dat kennelijk onbehoorlijk bestuur/toezicht onweerlegbaar vaststaat en ook niet het bewijsvermoeden dat dit bestuur/toezicht een belangrijke oorzaak is van het faillissement, indien in de periode van drie jaren die vooraf gingen aan het faillissement van de betrokken rechtspersoon niet aan de administratie- of publicatieplicht (van de jaarrekening) is voldaan.

Voor bestuurders en commissarissen bij stichtingen is voorts van belang dat de ontslagmogelijkheid via de rechtbank op verzoek van een belanghebbende ook van toepassing wordt op commissarissen en de ontslaggronden worden uitgebreid. $\mathrm{Na}$ invoering van de Wet bestuur en toezicht rechtspersonen kunnen bestuurders en commissarissen bij een stichting ook worden ontslagen wegens verwaarlozing van hun taak, wegens andere gewichtige redenen of wegens ingrijpende wijziging van omstandigheden, op grond waarvan het voortduren van hun bestuurderschap (of commissarisschap) in redelijkheid niet kan worden geduld. ${ }^{12}$

10 Zie hierover C.D.H. Bulten in haar noot onder Hof Amsterdam (Ondernemingskamer) 13 maart 2020, JOR 2020, 171, p. 2202.

11 Voor een groot deel van de zorginstellingen als bedoeld in de WTZi is dit thans geregeld in de Regeling verslaggeving WTZi.

12 Zie hierover, over het begrip belanghebbenden en de verhouding tussen deze ontslagmogelijkheden en het enquêterecht Van Uchelen-Schipper 2019, p. 74-76. 
Plomp ${ }^{13}$ en Klaassen ${ }^{14}$ zien in deze uitgebreide ontslagmogelijkheden door de rechtbank aanleiding om de aan de IGJ gemandateerde mogelijkheid ${ }^{15}$ tot het geven van aanwijzingen die ingrijpen in (de samenstelling van) het bestuur en de raad van toezicht van zorginstellingen, te heroverwegen. Dit zou mijns inziens zeker moeten gebeuren indien het toezicht van de IGJ ertoe leidt dat bestuurders en commissarissen worden geschorst of ontslagen op grond van een discutabele toepassing van normen die (enkel) gebaseerd zijn op het Kader goed bestuur of een nog niet vastgestelde (concept-) Uitvoeringsbesluit Wtza.

Ten slotte wordt ten aanzien van alle in Boek 2 BW geregelde rechtspersonen bepaald dat een bestuurder of commissaris niet meer stemmen mag uitbrengen dan de andere bestuurders of commissarissen tezamen. ${ }^{16}$ Ook moeten de statuten van deze rechtspersonen een belet- en ontstentenisregeling voor bestuurders en commissarissen bevatten. ${ }^{17}$

\section{De Wtza, de Awtza en het (concept-)Uitvoeringsbesluit Wtza}

De Wtza komt in de plaats van de Wet toelating zorginstellingen (WTZi). Het toelatingssysteem van de WTZi is relatief licht: het CIBG $^{18}$ toetst of nieuwe zorgaanbieders aan enkele randvoorwaarden voldoen. Het CIBG houdt er daarbij wel een vrij rigide toets van de in de toelichting op het Uitvoeringsbesluit WTZi opgenomen onafhankelijkheidsvereisten voor de RvT op na: indien die niet (letterlijk) in de statuten zijn opgenomen, is doorgaans een wijziging van de statuten vereist voordat een toelating wordt verleend. Voorts worden bepaalde zorginstellingen

13 E. Plomp, De Wet bestuur en toezicht rechtspersonen: een aanwinst voor de zorgsector, in: J.M. Blanco Fernández e.a., Bestuur en toezicht bij rechtspersonen, mede in de semipublieke en nonprofitsector, Zutphen: Uitgeverij Paris 2016, p. 142.

14 Klaassen 2017, p. 32.

15 De IGJ kan op grond van art. 27 Wkkgz een aanwijzing geven als de kwaliteit van zorg bij een zorginstelling niet in orde is. Zo'n aanwijzing kan in het uiterste geval zelfs strekken tot vervanging van een of meer bestuursleden of commissarissen. Zie Kamerstukken II 2015/16, 32012, nr. 35, p. 8. J.G. Sijmons, Over 'open normen' van goed bestuur en handhaving na invoering van de Wkkgz, TvGR (40) 2016, afl. 2, p. 90 merkt op dat via de omweg van de bestuurlijke verantwoordelijkheid voor de normschending er nog steeds geen grondslag in de Wkkgz is om in de open handhavingsbevoegdheid te lezen dat een maatregel kan zijn om een of meerdere bestuurders of toezichthouders te vervangen

16 Zie hierover $\mathrm{H}$. Koster, Wet bestuur en toezicht aangenomen door Tweede Kamer, Ondernemingsrecht 2020/46.

17 Zie over deze wijziging en het overgangsrecht dat van toepassing is of zou moeten zijn op het WBTR, J.D.M. Schoonbrood, Het overgangsrecht in het wetsvoorstel Bestuur en toezicht rechtspersonen, WPNR 30 mei 2020, afl. 7285, p. 404-410.

18 CIBG is een afkorting voor Centraal Informatiepunt Beroepen Gezondheidszorg. Deze naam wordt echter in de praktijk niet meer gebruikt. 'Het CIBG is een agentschap van het Ministerie van Volksgezondheid, Welzijn en Sport en zorgt voor een betrouwbare verzameling, verwerking en koppeling (gegevensknooppunten) van (gecertificeerde) gegevens en uitlevering aan gebruikers. Het CIBG heeft een breed takenpakket zoals het BIG-register, het Donorregister, Registerleraar en het UZI-register.' Zie MvT Wtza, Kamerstukken II 2016/17, 34767, nr. 3 (hierna: MvT Wtza), p. 4, noot 11 . 
van rechtswege (automatisch) toegelaten. Dit relatief soepele - behoudens voor zover dit de onafhankelijkheidsvereisten voor de RvT betreft bij instellingen die niet van rechtswege worden toegelaten - toelatingssysteem past bij de nadruk die met ingang van 2006 werd gelegd op marktwerking in de zorg met een beperkte rol voor de overheid.

Het systeem in de Wtza is veel strenger en bestaat uit drie onderdelen: (1) een meldplicht, (2) een vergunningplicht en (3) de eis van een onafhankelijke interne toezichthouder. Het doel van dit nieuwe systeem is om een betere controle door de IGJ mogelijk te maken op de kwaliteit van zorg bij nieuwe toetreders tot de zorg en bestaande zorgaanbieders. ${ }^{19}$

De Awtza bevat de verplichting voor alle zorgaanbieders als bedoeld in de Wet marktordening gezondheidszorg (Wmg) om een transparante financiële bedrijfsvoering te hebben. Voorts introduceert de Awtza een meldplicht voor bestaande en nieuwe jeugdhulpverleners onder de Jeugdwet. Ten slotte bevat deze wet regels voor handhaving van het verbod op winstuitkering, dat geldt tenzij in de lagere regelgeving daarvan wordt afgeweken. ${ }^{20}$

\subsection{De meldplicht}

De meldplicht brengt mee dat nieuwe zorgaanbieders (voordat zij beginnen met het verlenen van zorg) en bestaande zorgaanbieders (binnen zes maanden na inwerkingtreding van de Wtza) zich moeten melden bij de IGJ, zodat deze in beeld zijn ten behoeve van het risicogestuurde toezicht van deze toezichthouder. Daarnaast is de meldplicht volgens de nota van toelichting op dit conceptbesluit erop gericht 'om nieuwe zorgaanbieders beter bewust te maken van de landelijke (kwaliteits)eisen die aan de zorgverlening zijn gesteld en hun verantwoordelijkheid hiervoor'.

Volgens deze nota zal deze meldplicht gelden voor zorgaanbieders die 'zorg als bedoeld bij of krachtens de Wet kwaliteit, klachten en geschillen zorg willen gaan verlenen of doen verlenen.' Onder deze zorg moet dan volgens deze nota worden verstaan: 'zorg verleend op basis van de Wet langdurige zorg (Wlz), de Zorgverzekeringswet (Zvw) en andere zorg'. ${ }^{21}$ In de praktijk is daarmee de meldplicht breed: deze geldt niet alleen voor bijvoorbeeld eerstelijnszorg, ziekenhuizen, verpleeghuizen en wijkverpleging, maar ook voor aanbieders van onder andere cosmetische zorg, alternatieve geneeswijzen, bevolkingsonderzoek en voor gemeentelijke gezondheidsdiensten'.

19 Zie MvT Wtza, p. 6.

20 Zie voor een heldere en bondige samenvatting van de Wtza en de Awtza B. Megens, Zorgaanbieders, hoed u voor de nieuwe plichten Wtza, Zorgvisie 12 februari 2020.

21 In de Wkkgz gedefinieerd als: "handelingen op het gebied van de individuele gezondheidszorg als bedoeld in artikel 1 van de Wet op de beroepen in de individuele gezondheidszorg, niet zijnde Wlz-zorg of Zvw-zorg, alsmede handelingen met een ander doel dan het bevorderen of bewaken van de gezondheid van de cliënt'. 
Deze meldplicht betreft zowel hoofdaannemers als onderaannemers. Dit betekent dat bijvoorbeeld ook Medisch Specialistische Bedrijven (MSB's) zich moeten melden. De brede reikwijdte van de meldplicht moet ertoe leiden dat alle zorgaanbieders (zowel instellingen als solistisch werkende zorgverleners) die zorg als bedoeld bij of krachtens de Wet kwaliteit, klachten en geschillen zorg (Wkkgz) verlenen, tijdig in beeld komen bij de IGJ.

\subsection{De vergunningplicht}

De groep zorgaanbieders die onder de vergunningplicht valt, is veel beperkter. Alleen de nieuwe en bestaande zorgaanbieders die medisch specialistische zorg (doen) verlenen, dan wel met meer dan tien zorgverleners (inclusief uitbesteding) zorg of een dienst als omschreven bij of krachtens de Wlz of de Zvw (doen) verlenen, zijn vergunningplichtig.

De vergunningplicht betreft alleen instellingen en geldt niet voor solistisch optredende zorgverleners. Voorts zijn alleen hoofdaannemers vergunningplichtig in de zin van de Wtza.

Bestaande instellingen die op basis van een actieve toetsing een WTZi-toelating hebben verkregen, krijgen in plaats daarvan van rechtswege een Wtza-vergunning als de betrokken instelling over een Wtza-vergunning moet beschikken. Dit geldt niet voor bestaande zorgaanbieders die van rechtswege een WTZi-toelating hebben verkregen. Voor hen geldt een overgangstermijn van twee jaar na inwerkingtreding van de Wtza, waarbinnen zij alsnog een vergunning moeten aanvragen. Deze overgangstermijn is ook van toepassing op zorgaanbieders die onder de WTZi niet behoefden te worden toegelaten, maar onder de Wtza wel een vergunning moeten hebben. Een voorbeeld hiervan zijn de aanbieders van niet-verzekerde cosmetische zorg.

Het (concept-)Uitvoeringsbesluit Wtza zondert bepaalde zorgaanbieders uit van de meldplicht en/of de vergunningplicht. Zo zijn abortusklinieken en regionale ambulancevoorzieningen niet meld- en vergunningplichtig ${ }^{22}$ en zijn apotheken die ingeschreven staan in het apothekenregister alleen vergunningplichtig. ${ }^{23}$

22 In de toelichting op het (concept-)Uitvoeringsbesluit Wtza wordt hierover onder meer het volgende opgemerkt: 'Abortusklinieken zijn in beeld bij de IGJ wanneer zij over een vergunning beschikken als bedoeld in artikel 2 van de Wet afbreking zwangerschap. Het wordt daarom niet nodig geacht dat abortusklinieken die over een vergunning als bedoeld in voornoemde wet beschikken, onder de meldplicht vallen. Via de vereisten die ten aanzien van zodanige vergunning gelden, moeten abortusklinieken aan bepaalde eisen voldoen omtrent onder meer bestuur en beheer van de kliniek en verslaggeving van de gang van zaken op medisch en financieel gebied. Het wordt daarom evenmin nodig geacht dat abortusklinieken onder de vergunningplicht van de Wtza vallen.'

23 In de toelichting op het (concept-)Uitvoeringsbesluit Wtza wordt hierover onder meer het volgende opgemerkt: 'Apotheken waarvan de apotheker die is belast met de leiding van de apotheek is ingeschreven in het register, bedoeld in artikel 61, vijfde lid, van de Geneesmiddelenwet, zijn reeds in beeld bij de IGJ. Om die reden worden deze apotheken uitgezonderd van de meldplicht. (...) 


\subsection{Bestuursstructuur (onafhankelijke interne toezichthouder)}

Art. 3 lid 1 Wtza bepaalt dat zorgaanbieders die op grond van de Wtza vergunningplichtig zijn aan de volgende eisen omtrent de bestuursstructuur moeten voldoen:

a Er is een interne toezichthouder die toezicht houdt op het beleid van de dagelijkse of algemene leiding van de instelling en die dagelijkse of algemene leiding van de instelling met raad terzijde staat.

b Een persoon maakt niet tegelijk deel uit van de interne toezichthouder en de dagelijkse of algemene leiding van de instelling.

c De interne toezichthouder is zodanig samengesteld dat de leden ten opzichte van elkaar, de dagelijkse of algemene leiding van de instelling en welk deelbelang dan ook onafhankelijk en kritisch kunnen opereren.

d De instelling legt op inzichtelijke wijze de verantwoordelijkheidsverdeling tussen de interne toezichthouder en de dagelijkse of algemene leiding vast, alsmede de wijze waarop interne conflicten tussen de interne toezichthouder en de dagelijkse of algemene leiding worden geregeld.

In lid 2 van art. 3 Wtza wordt geregeld dat bij algemene maatregel van bestuur (amvb) nadere eisen (die per categorie van zorgaanbieders kunnen verschillen) kunnen worden gesteld betreffende de bestuursstructuur waaraan een Wtza-vergunningplichtige zorgaanbieder moet voldoen. Deze eisen hebben in ieder geval betrekking op:

a de waarborging van de onafhankelijke taakvervulling door de interne toezichthouder;

b de samenstelling van de interne toezichthouder;

c de verstrekking van inlichtingen aan de interne toezichthouder;

d de taken en bevoegdheden van de interne toezichthouder.

Lid 4 van art. 3 Wtza bepaalt dat eveneens bij amvb categorieën van Wtza-vergunningplichtige zorgaanbieders kunnen worden aangewezen waarop de eisen omtrent de bestuursstructuur niet van toepassing zijn.

Belangrijk zijn de uitzonderingen die het (concept-)Uitvoeringsbesluit Wtza maakt op de eisen voor de bestuurs- en toezichtstructuur voor bepaalde kleine zorgaanbieders. Dit betreft (1) instellingen die in de regel met 10 of minder zorgverleners medisch specialistische zorg (doen) verlenen en (2) ambulante instellingen die in de regel met minder dan 25 zorgverleners Wlz- of Zvw-zorg (doen) verlenen, mits die geen medisch specialistische zorg of persoonlijke verzorging, begeleiding of verpleging als bedoeld in de $\mathrm{Wlz}$ of het Besluit Zorgverzekering (vrij vertaald: wijkverpleging) aanbieden. ${ }^{24}$ Dit betekent dat kleine (eerstelijns) zorgaanbieders zoals huisartsenpraktijken, verloskundepraktijken en kraamzorginstellingen geen $\mathrm{RvT} / \mathrm{RvC}$ hoeven in te stellen en ook niet aan de overige eisen 
van de Wtza en het (concept-)Uitvoeringsbesluit Wtza met betrekking tot de bestuursstructuur hoeven te voldoen. ${ }^{25}$

Dat de Wtza-wetgever pragmatisch wil zijn, juich ik toe. De regeldruk voor met name kleine zorgaanbieders moet niet te zwaar worden. Ik ben echter van mening dat de grens van 10 of 25 zorgverleners veel te laag is om te kunnen voldoen aan de hierna te bespreken plicht om een driehoofdige raad van toezicht in te stellen. Een grens van 50 zorgverleners lijkt mij wel werkbaar. ${ }^{26}$

Het (concept-)Uitvoeringsbesluit Wtza voegt voor niet-uitgezonderde zorgaanbieders ook regels toe, die eerder geen deel uitmaakten van het Uitvoeringsbesluit WTZi.

In de nota van toelichting van dit (concept-)Uitvoeringsbesluit ${ }^{27}$ wordt art. 3 lid 1 sub a Wtza zo uitgelegd dat bij iedere rechtspersoon waarop dit artikel van toepassing is een afzonderlijke interne toezichthouder moet worden ingesteld. Bij een holdingstructuur moet(en) de interne toezichthouder(s) direct toezicht kunnen houden op de activiteiten van dochterondernemingen, 'anders zou sprake zijn van "getrapt" toezicht en ontstaat het risico dat de interne toezichthouder mogelijke risico's voor de instelling onvoldoende kan overzien'.

Speciaal voor instellingen die in een groep en/of als dochtermaatschappij met een andere instelling verbonden zijn, bevat art. 7 lid 1 sub b (concept-)Uitvoeringsbesluit Wtza een uitzondering op het daarin opgenomen verbod voor leden van een interne toezichthouder van de instelling om tevens lid te zijn van een interne toezichthouder van een andere instelling die binnen het verzorgingsgebied van de instelling geheel of gedeeltelijk dezelfde werkzaamheden verricht. Dit maakt het mogelijk dat leden van de toezichthouder van de holding tevens deel uitmaken

25 Voorts geldt een belangrijke - en logische - uitzondering voor academische ziekenhuizen: de governance van zowel de openbare als de bijzondere academische ziekenhuizen is afzonderlijk geregeld in de Wet op het hoger onderwijs en wetenschappelijk onderzoek (WHW).

26 Welk bedrijf met tien medewerkers heeft nu een interne toezichthouder met drie leden? Wat draagt dit bij aan een goed bestuur van dit bedrijf? Hoeveel extra commissarissen moeten er dan zijn in Nederland? Hoe hoog mag en kan de beloning van deze commissarissen in het kader van de Wet normering topinkomens (WNT) dan zijn? En hoe verhoudt deze ongetwijfeld geringe beloning zich dan met de verantwoordelijkheid en hoofdelijke aansprakelijkheid van deze commissarissen?

27 NvT (concept-)Uitvoeringsbesluit Wtza, p. 9. 
van een of meer interne toezichthouders van instellingen die dochtermaatschappij en/of groepsmaatschappij van de holding zijn. ${ }^{28}$

Voorts moet de RvC/RvT bestaan uit ten minste drie natuurlijke personen. De leden van dit orgaan mogen voor ten hoogste vier jaar worden aangesteld. Deze periode kan eenmaal met ten hoogste vier jaar worden verlengd. De al dan niet aaneengesloten totale periode waarin een persoon lid mag zijn van de $\mathrm{RvC} / \mathrm{RvT}$ is ten hoogste acht jaar.

Deze regel die de zittingsperiode van interne toezichthouders maximeert, vinden wij ook al terug in best practice bepaling 6.2.3 van de Governancecode Zorg 2017.

Indien er al getwijfeld kon worden of van deze bepaling met een duidelijke en plausibele uitleg kan worden afgeweken, is het antwoord na ongewijzigde vaststelling van het (concept-)Uitvoeringsbesluit Wtza klip-en-klaar. Dit kan niet als op de betrokken zorgaanbieder de bepalingen van de Wtza en het Uitvoeringsbesluit Wtza omtrent de bestuursstructuur van toepassing zijn.

Mijns inziens is dit geen wenselijke ontwikkeling! Wat als het belang van de betrokken zorgaanbieder wordt geschaad omdat op het moment van het verstrijken van de achtjaarstermijn de betrokken commissaris vanwege een acute situatie die de continuïteit van de zorginstelling bedreigt, niet gemist kan worden? Gedacht kan worden aan de situatie dat haar/zijn deskundigheid en ervaring nodig zijn om goed toe te zien op een urgente herstructurering (van de onderneming) van de zorginstelling. Zou het dan onmogelijk moeten zijn de aanstelling van deze commissaris met een paar maanden te verlengen ${ }^{29}$

28 Uiteraard moet wel rekening worden gehouden met de beperkingen in Boek 2 BW voor het aantal commissariaten en bestuurslidmaatschappen die een bestuurder of commissaris bij een 'grote' nv, bv of stichting mag hebben. Een persoon mag niet tot bestuurder van een grote nv, bv of stichting worden benoemd indien de betrokkene bij meer dan twee andere rechtspersonen commissaris of niet-uitvoerend bestuurder is. De voorzitter van de RvC/RvT of een one tier board kan geen bestuursfunctie bij een grote nv, bv of stichting bekleden. Commissarissen bij grote rechtspersonen mogen bij maximaal vijf rechtspersonen functioneren als commissaris of nietuitvoerend bestuurder. De rol van voorzitter van een $\mathrm{RvC}$ of one tier board telt bij deze telling voor twee. Zie (a) voor de stichting art. 2:297a BW (criteria voor bestuurders) en art. 2:297b BW (criteria voor commissarissen), (b) voor de nv art. 2:132a BW (criteria voor bestuurders) en art. 2:142a BW (voor commissarissen) en (c) voor de bv art. 2:242a BW (criteria voor bestuurders) en art. 2:242b BW (voor commissarissen). Een rechtspersoon is 'groot' in de zin van deze artikelen indien deze op twee opeenvolgende balansdata zonder onderbreking aan ten minste twee van de volgende vereisten voldoet: (1) de balanswaarde van de activa bedraagt meer dan $€ 20$ miljoen, (2) de omzet bedraagt meer dan $€ 40$ miljoen, en (3) het gemiddelde aantal werknemers is meer dan 250. Voor stichtingen geldt nog de aanvullende eis dat deze pas als 'groot' kwalificeren als zij een financiële verantwoording moeten opstellen die gelijk of gelijkwaardig is aan de jaarrekening zoals bedoeld in titel 9 van Boek 2 BW (zie art. 2:297a lid 1 BW). Zie hierover Schmieman, in: T\&C BW 2019, art. 2:297a, waarin overigens nog de oude lagere grensbedragen voor een 'grote' stichting worden genoemd.

29 Hoe zit het voorts met de handhaafbaarheid? Gaat de IGJ of de NZa voor elk lid van de interne toezichthouder van een zorginstelling controleren of deze langer dan acht jaar - al dan niet ononderbroken - in functie is? 
Het (concept-)Uitvoeringsbesluit Wtza is bijzonder streng voor zover het de onafhankelijkheid van de leden van de $\operatorname{RvT} / \operatorname{RvC}$ betreft. Zo bepaalt art. 7 onder andere dat

'een lid van de interne toezichthouder, diens echtgenoot of andere levensgezel, pleegkind of bloed- en aanverwant tot in de tweede graad: 1e tijdens dan wel in de periode van drie jaar voorafgaand aan het lidmaatschap van de interne toezichthouder geen lid is van de dagelijkse of algemene leiding van de instelling; 2e in de periode van een jaar voorafgaand aan het lidmaatschap van de interne toezichthouder niet tijdelijk heeft voorzien in de dagelijkse of algemene leiding van de instelling; 3e tijdens dan wel in de periode van drie jaar voorafgaand aan het lidmaatschap van de interne toezichthouder geen werknemer van de instelling is; (...) 6e geen aandelen in de instelling houdt; 7 e geen lid is van de dagelijkse of algemene leiding van een rechtspersoon die aandelen in de instelling houdt dan wel van een andere instelling die binnen het verzorgingsgebied van de instelling geheel of gedeeltelijk dezelfde werkzaamheden verricht.'

In de nota van toelichting bij het (concept-)Uitvoeringsbesluit Wtza ${ }^{30}$ wordt hierover onder meer het volgende gezegd:

'Onafhankelijkheid vereist uitsluiting van (de schijn van) financiële, personele of familiale belangenverstrengeling van de interne toezichthouder met (de dagelijkse of algemene leiding van) de instelling. Wanneer in ieder geval sprake is van belangenverstrengeling is neergelegd in dit artikel.'

Wederom zit ik op dezelfde lijn als Van Uchelen-Schipper, ${ }^{31}$ die opmerkt dat het voorkomen van belangenverstrengeling een belangrijk thema is in veel sectorale governancecodes: 'Dergelijke bepalingen dienen wel aan te sluiten bij de wettelijke basisregeling.' Hetzelfde geldt mijns inziens voor sectorale wetten en uitvoeringsbesluiten. Indien er in zo'n sectorwet of uitvoeringsbesluit een strengere regel wordt ingevoerd, zou dit vergezeld moeten gaan met een concludente redenering waarom de aard van de betrokken semipublieke instelling deze strengere regel vergt.

Voor de meeste verboden is wel voorzien in een summiere redenering in de nota van toelichting Uitvoeringsbesluit Wtza, maar deze is meestal niet concludent. Een voorbeeld daarvan is de volgende passage, ${ }^{32}$ die het verbod voor leden van de interne toezichthouder (alsmede hun familieleden) om aandelen in de zorginstelling te houden, zou moeten verklaren: 
'In subonderdeel $6 \mathrm{e}$ is opgenomen dat leden van een interne toezichthouder en hun familieleden geen aandelen in de instelling mogen houden. De interne toezichthouder richt zich bij zijn taak immers naar het belang van de instelling, het te behartigen maatschappelijk belang en het belang van de betrokken belanghebbenden. Aandeelhouders hebben een eigen belang en dat belang laat zich niet goed verenigen met de taak van de interne toezichthouder.'

Deze redenering kan ik niet volgen. Waarom zouden de belangen van aandeelhouders zich niet goed laten verenigen met het belang van de zorgaanbieder? Aandeelhouders behoren immers tot de betrokken belanghebbenden, hebben baat bij de continuïteit van de zorgaanbieder en hebben er bij het kopen of nemen van hun aandelen voor gekozen om te investeren in een rechtspersoon met een maatschappelijke doelstelling!

De belangen van deze aandeelhouders zullen derhalve vaak parallel lopen met het belang van de instelling, het te behartigen maatschappelijk belang en het belang van de betrokken belanghebbenden. Waar dat niet het geval is, biedt de wettelijke tegenstrijdigbelangregeling, die nu al geldt voor de nv en bv en straks voor alle Boek 2 BW-rechtspersonen zal gelden, uitkomst. Bij een persoonlijk tegenstrijdig belang moet het betrokken lid van de interne toezichthouder zich terugtrekken uit de beraadslaging en besluitvorming omtrent het te nemen besluit.

Het (concept-)Uitvoeringsbesluit Wtza biedt geen uitweg voor een zorginstelling die in de vorm van een bv of nv wordt gedreven en waarbij een of meer aandeelhouders in de $\mathrm{RvC}$ zitten. Hoe integer zij ook zijn en zelfs als zij aangeven te allen tijde het belang van de zorginstelling voorop te willen stellen, geldt immers voor hen het verbod om aandelen in de zorginstelling te houden! Dit betekent dat bijvoorbeeld twee artsen die samen met een venture capital fund of een private equity fund aandelen houden in een joint-venture-bv, die een of meer klinieken in stand houdt, niet in de $\mathrm{RvC}$ van deze bv plaats kunnen nemen. In de $\mathrm{RvC}$ zouden zij samen met een aantal 'onafhankelijke' commissarissen mijns inziens prima toezicht kunnen houden op een professionele bestuurder. Met name als deze bestuurder geen arts is, heeft hun lidmaatschap een belangrijke toegevoegde waarde voor het toezicht op de kwaliteit van de zorg die door deze klinieken wordt geleverd. Ik begrijp ook niet waarom de opsteller van het (concept-)Uitvoeringsbesluit niet de gulden middenweg heeft gekozen door te bepalen dat de meerderheid van de leden onafhankelijk moet zijn, in die zin dat zij geen aandelen in de zorginstelling mogen houden. Dat klemt temeer daar onder de 'oude' Zorgbrede Governancecode het comply-or-explainbeginsel gold: daar kon men - mits dat de bestuurbaarheid ten goede kwam - prima afwijken van de 'onafhankelijkheidsregel' en dus een aandeelhouderscommissaris benoemen. Dat klemt nog meer daar onder het gesneuvelde wetsvoorstel 'Wijziging van de Wet cliëntenrechten zorg en enkele andere wetten om het mogelijk te maken dat aanbieders van medisch-specialistische zorg, mits zij aan een aantal voorwaarden voldoen, 
winst uitkeren (voorwaarden voor winstuitkering aanbieders medisch-specialistische zorg)' een aandeelhouderscommissaris ook zou zijn toegestaan:

'Om ervoor te zorgen dat zorgaanbieders, met of zonder aandeelhouders, goed bestuurd worden, zal de Wcz de bestuursstructuur van zorgaanbieders sterk verbeteren. Zo worden de positie van de raad van toezicht en de cliëntenraad versterkt en worden eisen over de onafhankelijkheid gesteld. Deze gaan echter niet zo ver dat aandeelhouders als lid van de raad van toezicht zijn uitgesloten. 33

Of vloeit het absolute verbod voor leden van interne toezichthouders van zorgaanbieders om aandelen te bezitten al voort uit de volgende in best practice bepaling 2.6.1 van de Governancecode Zorg 2017 neergelegde norm: 'Elke vorm van persoonlijke bevoordeling dan wel belangenverstrengeling van enig lid van de raad van bestuur of van de raad van toezicht en de zorgorganisatie wordt voorkomen en de schijn hiervan wordt vermeden'?

Als dat zo is, geldt dan hetzelfde voor bestuurders van zorgaanbieders die aandelen in de nv of bv die de betrokken zorgaanbieder in stand houdt, bezitten? Is hun aandeelhouderschap dan wel verenigbaar met de in de Governancecode Zorg 2017 neergelegde plicht om zich te richten 'op het belang van de zorgorganisatie op korte en lange termijn, vanuit het perspectief van de maatschappelijke doelstelling van de zorgorganisatie en de centrale positie van de cliënt daarin'? ${ }^{34}$

Of ziet de opsteller van het (concept-)Uitvoeringsbesluit Wtza de interne toezichthouder aals de (enige) waakhond van de voornoemde belangen en moeten de commissarissen van zorgaanbieders zich opmaken voor een (machts)strijd met de bestuurders? Daar lijkt het wel op, als wij de volgende passages uit de nota van toelichting ${ }^{35}$ lezen:

'Onafhankelijkheid vereist uitsluiting van (de schijn van) financiële, personele of familiale belangenverstrengeling van de interne toezichthouder met (de dagelijkse of algemene leiding van) de instelling.'

En:

'In het algemeen geldt dat een onafhankelijke interne toezichthouder een belangrijke functie heeft als adviseur van, en tegenmacht voor, de dagelijkse of algemene leiding van een zorgorganisatie.'

34 Uit het feit dat bij de parlementaire behandeling van de Awtza een amendement dat ertoe strekt dat een 'constructie' waarin een bestuurder zelf een financieel belang heeft nooit winst mag uitkeren, werd verworpen, leid ik af dat de wetgever het (direct of indirect) houden van aandelen in een zorginstelling door haar bestuurder vooralsnog niet wil verbieden. Megens 2020 merkt hierover op dat het met oog op de wens van de politiek om de mogelijkheid van gereguleerde winstuitkering in de zorg verder te onderzoeken en zorgvuldiger vorm te geven weinig verrassend is dat men daarop niet wil vooruitlopen. 
Ik vind het woord 'tegenmacht' hier ongelukkig gekozen. Het gaat er toch om dat het bestuur en de interne toezichthouder zo veel mogelijk samen optrekken? Dit geldt ook voor hun overleg met cliënten(raden), medewerkers en ondernemingsraden. Toezicht houden betekent in de eerste plaats het kritisch volgen aan de hand van de doelstellingen, die geformuleerd zijn door het bestuur.

Art. 8 (concept-)Uitvoeringsbesluit Wtza bepaalt dat de interne toezichthouder zich bij de vervulling van zijn taak richt naar het belang van de instelling, het te behartigen maatschappelijk belang en het belang van de betrokken belanghebbende. Ik ben het eens met Van Uchelen-Schipper, die opmerkt dat '[dergelijke; WO] algemene taken en normstellingen in sectorcodes en sectorwetten kunnen worden geschrapt'. Zij acht het overbodig en verwarrend dat sommige sectorale regels bepalen dat bestuurders en leden van de $\mathrm{RvT} / \mathrm{RvC}$ zich mede moeten richten op het maatschappelijk belang, aangezien dit op grond van de algemene norm reeds een van de belangen is waarmee bestuurders en commissarissen rekening moeten houden. ${ }^{36}$

\section{Verhouding tussen de Wtza, het (concept-)Uitvoeringsbesluit Wtza en het WBTR}

De zogenoemde 'one tier board' wordt in art. 3 lid 1 sub c Wtza verboden. Dit is opvallend, omdat het hierna te behandelen WBTR de one tier board voor alle rechtspersonen uit Boek 2 BW (en dus ook voor de stichting, die de meest voorkomende rechtsvorm van zorgaanbieders is) wettelijk faciliteert.

Volgens de MvT Wtza ${ }^{37}$ is de eis dat een persoon niet tegelijkertijd deel mag uitmaken van de interne toezichthouder en de dagelijkse of algemene leiding van de instelling, ontleend aan art. 6.1 van het Uitvoeringsbesluit WTZi. ${ }^{38}$ Een nadere motivatie - bijvoorbeeld dat en waarom een one tier board voor een instelling met een semipublieke taak minder geschikt is - voor het overnemen van deze eis wordt niet gegeven. Enige motivering had wat dit betreft - zeker nu hier in de literatuur ${ }^{39}$ de nodige kritiek op is geuit - niet misstaan. Mij is niet duidelijk waarom de wetgever de one tier board wel geschikt acht voor iedere andere rechtspersoon, maar niet voor een rechtspersoon die Wtza-vergunningplichtig is.

In het (concept-)Uitvoeringsbesluit Wtza worden - anders dan in het WBTR scherpe onafhankelijkheidseisen gesteld aan leden van de interne toezichthouder. Zelfs de 'schijn van belangenverstrengeling' moet worden tegengegaan.

Van Uchelen-Schipper 2019, p. 72.

NvT (concept-)Uitvoeringsbesluit Wtza, p. 26.

Overigens werd die toelichting ook onder de WTZi niet echt gegeven: als gevolg van 'schaalvergroting' en 'professionalisering' moest de onafhankelijkheid van de RvT worden geborgd. Zowel een bestuur-directiemodel als een RvT-RvB-model werd toegestaan, maar de one tier board niet. Zie Klaassen 2017, p. 22 en in bedekte termen Van Uchelen-Schipper 2019, p. 71. 
Geen rekening lijkt daarbij te worden gehouden met de werking van de tegenstrijdigbelangregeling uit Boek $2 \mathrm{BW}$, waardoor een lid van de $\mathrm{RvC} / \mathrm{RvT}$ zich bij een persoonlijk tegenstrijdig belang uit de beraadslaging en besluitvorming omtrent het betrokken besluit dient terug te trekken. De regeling sluit wel aan bij de Governancecode Zorg 2017, maar is veel digitaler. Bij de 'schijn van belangenverstrengeling' die zou worden gewekt door het feit dat een commissaris aandelen houdt in de nv of bv die de betrokken zorgorganisatie in stand houdt, bestaat in de Code nog een ontsnappingsmogelijkheid:

'In de reglementen van de raad van bestuur en raad van toezicht wordt vastgelegd hoe met tegenstrijdige belangen en de schijn hiervan wordt omgegaan. Een lid van de raad van bestuur of de raad van toezicht meldt elke vorm en/of schijn van belangenverstrengeling terstond aan de voorzitter van de raad van toezicht en aan de overige leden van de raad en verschaft daarover alle informatie. De raad van toezicht besluit buiten aanwezigheid van het betrokken lid of er sprake is van belangenverstrengeling en hoe hiermee wordt omgegaan.'

Hoewel - ten opzichte van de onschuldpresumptie uit het strafrecht - de bewijslast wordt omgedraaid, biedt deze bepaling toch ook nog mogelijkheden om met de schijn van belangenverstrengeling om te gaan. Een lid van de $\mathrm{RvC} / \mathrm{RvT}$ ten opzichte van wie de schijn van belangenverstrengeling bestaat, hoeft deze schijn niet op straffe van schorsing of ontslag op te heffen. Deze schijn kan kennelijk worden weerlegd of er kan een wijze worden gevonden om met deze schijn om te gaan. Ten slotte zou kunnen worden uitgelegd dat toepassing van de Code in deze situatie niet wenselijk is. ${ }^{40}$

\section{Verhouding Kader goed bestuur met nieuwe regelgeving en noden van de praktijk}

Hoe verhoudt voornoemde aanscherping van de regeling in het Kader goed bestuur zich nu tot de aanpassing van de regels in Boek 2 BW?

Allereerst kan worden geconstateerd dat de verhouding tussen en de taken van respectievelijk bestuurders en commissarissen bij invoering van dit wetvoorstel niet worden veranderd, maar juist voor stichtingen en verenigingen wettelijk worden vastgelegd. Het bestuur bestuurt en de $\mathrm{RvC} / \mathrm{RvT}$ houdt toezicht op het beleid van het bestuur en de algemene zaken in de rechtspersoon en de daaraan verbonden onderneming of organisatie. $\mathrm{De} \operatorname{RvC} / \mathrm{Rv} T$ staat het bestuur voorts met raad terzijde.

$40 \mathrm{Al}$ moet worden toegegeven dat de Governancecommissie Gezondheidszorg (Gc) hier blijkens haar beslissing d.d. 26 februari 2019, Gc18/03, niet bepaald soepel mee omgaat. Zie voor kritiek hierop W.J. Oostwouder \& T. Spronk, Twee heren (in één transactie) dienen, mag dat nu wel of (soms) toch niet?, O\&F (27) 2019, afl. 3, p. 24-25. 
Maar wat lezen wij in het derde thema uit het nieuwe Kader goed bestuur, waaraan raden van toezicht uitvoering moeten geven?

\section{'De raad van toezicht dient ook het maatschappelijk belang over de grenzen van de eigen organisatie}

De raad van toezicht dient vooral de evenwichtige belangenafweging te waarborgen en spreekt de raad van bestuur hierop aan. Organisatiebelang, maatschappelijk belang en de belangen van betrokkenen - voor de korte en lange termijn - maken hier onderdeel van uit. Als het gaat om continuïteit, toegankelijkheid en betaalbaarheid van de zorg kijkt de raad van toezicht over de grenzen van de eigen organisatie heen. De raad van toezicht en het bestuur hebben een gezamenlijke visie op netwerk- en ketenzorg in de regio en hebben aandacht voor de governance daarvan. De maatschappelijke belangen zijn regelmatig onderwerp van gesprek met netwerk- en ketenpartners. ${ }^{21}$

Zoals hiervoor aangegeven wordt in het WBTR voor iedere in Boek 2 BW geregelde rechtspersoon vastgelegd dat diens bestuurders en commissarissen zich moeten richten op het belang van de rechtspersoon en de daaraan verbonden onderneming (of organisatie). Uit het Cancun-arrest van de Hoge $\operatorname{Raad}^{42}$ kan worden afgeleid dat indien aan een rechtspersoon een onderneming is verbonden, dit belang in belangrijke mate wordt bepaald door de continuïteit van deze onderneming. Zeker als straks in de wet als onderdeel van het belang van de stichting en de vereniging het begrip organisatie naast het begrip onderneming wordt genoemd, mag worden aangenomen dat hetzelfde geldt voor de continuïteit van de organisatie als aan een stichting of vereniging een organisatie is verbonden, die niet kwalificeert als onderneming.

Het bestuur en de RvC/RvT van een zorginstelling moeten uiteraard ook rekening houden met de maatschappelijke doelstelling van de zorginstelling. Wat is of zou de maatschappelijke doelstelling van een zorginstelling/zorgorganisatie moeten zijn?

De Governancecode Zorg 2017 geeft hier in haar eerste principe een duidelijk antwoord op:

'De maatschappelijke doelstelling en legitimatie van de zorgorganisatie is het bieden van goede zorg aan cliënten. ${ }^{43}$

Een zorgorganisatie mag natuurlijk bredere maatschappelijke doelen nastreven, maar dit behoort mijns inziens niet ten koste te gaan van het belang van de rechtspersoon en de daaraan verbonden onderneming of organisatie (en dus ten

41 Zie Van Uchelen-Schipper 2019, p. 72.

42 HR 4 april 2014, ECLI:NL:HR:2014:797, RvdW 2014/547, NJ 2014/286, m.nt. P. van Schilfgaarde (Cancun Holding II).

43 Zie www.governancecodezorg.nl/wp-content/uploads/2016/11/Governancecode-Zorg-2, p. 7. 
koste van de continuïteit daarvan), het statutaire doel van de rechtspersoon en het bieden van goede zorg aan cliënten.

Dit gaat niet altijd goed. Het bekendste voorbeeld van een doorgeslagen focus op een brede maatschappelijke doelstelling van de betrokken zorgorganisatie is de casus van de in 2015 gefailleerde Riagg-instelling Rijnmond.

Uit onderzoek van het $\mathrm{NRC}^{44}$ bleek dat de bestuurder van deze instelling zich verzette tegen de nieuwe manier van declareren in de zorg: 'Daardoor werd er niet goed geregistreerd en gefactureerd en kreeg de Riagg te weinig geld binnen.'

De bestuurders werden daarin kennelijk gesteund door de RvT, die zelfs niet ingreep toen het bankkrediet van de instelling werd opgezegd. De voorzitter van de RvT zag het opgezegde krediet niet als noodsignaal: 'Het was volgens hem onderdeel van een machtsstrijd tussen zorginstellingen, banken en verzekeraars.'

Het bestuur en de RvT vonden hun visie op de wijze waarop de zorg moest worden gefinancierd en het daarmee gepaard gaande door hen gepercipieerde maatschappelijk belang om zich tegen marktwerking in de zorg te verzetten, kennelijk zwaarder wegen dan het voortbestaan van hun instelling. Dit voorbeeld geeft aan hoe gevaarlijk het is als bestuurders en commissarissen ten koste van de continuïteit van de zorginstelling algemene maatschappelijke doelstellingen nastreven.

Dit zouden de IGJ en de NZa moeten tegengaan en niet stimuleren door van de $\mathrm{RvC} / \mathrm{Rv} \mathrm{T}$ te verlangen dat deze ook het maatschappelijk belang over de grenzen van de eigen organisatie moet dienen!

Voorts wekken de bewoordingen van dit thema de indruk dat de interne toezichthouder bij het over de grenzen van de eigen organisatie heen kijken als het gaat om 'continuïteit, toegankelijkheid en betaalbaarheid van zorg', het initiatief neemt en mede de 'gezamenlijke visie op netwerk- en ketenzorg in de regio' opstelt.

In iedere commissarissenopleiding wordt de deelnemers op het hart gedrukt dat commissarissen vooral niet op de stoel van de bestuurder moeten gaan zitten. Dit thema lijkt de RvC/RvT hier juist wel toe aan te zetten!

Als wij echter in het Kader goed bestuur ${ }^{45}$ lezen wat van bestuurders wordt verwacht, dan wordt alleen verwezen naar (gedrag, cultuur en systemen van) de eigen organisatie:

'Het bestuur behoort altijd zicht te hebben op de staat van de eigen organisatie en "in control" te zijn. Het bestuur weet waar de risico's zich voordoen en welke thema's aandacht nodig hebben. De informatie ontleent het bestuur aan velerlei metingen, onderzoeken en controlemechanismen. Controle en monitoring zijn daarbij de basis van een continu leerproces. (...) Van belang zijn ook de systematische verbeteracties en een aanspreekcultuur. Wij ver- 
wachten dat interne toezichthouders deze gesprekken stimuleren, eventueel eraan deelnemen, en de verbeteracties in de gaten houden.'

Zo hoort het! Het bestuur bestuurt, zet de lijnen uit en is verantwoordelijk voor de risicobeheersing. De interne toezichthouders stimuleren, controleren en geven advies.

Het vijfde thema uit het nieuwe Kader goed bestuur luidt als volgt:

\section{'De raad van toezicht borgt onafhankelijkheid en voorkomt vermen- ging van belangen}

De raad van toezicht ziet erop toe dat geld dat bedoeld is voor de zorg ook aan de zorg wordt besteed en dat de inrichting van de organisatie hier dienstbaar aan is. Leden van de raad van toezicht voorkomen elke schijn van vermenging van belangen bij henzelf en zij zien toe op het voorkomen van belangenverstrengeling. (...) $)^{46}$

Met de plicht voor de RvT om elke vorm van belangenverstrengeling bij henzelf te voorkomen loopt dit kader - zonder ontsnappingsmogelijkheid indien er geen daadwerkelijke belangenverstrengeling blijkt te zijn - vooruit op de digitale aanpak, die in het (concept-)Uitvoeringsbesluit Wtza is voorzien. Bovendien wordt dit niet beperkt tot de categorieën zorgaanbieders die bij het van kracht worden van het Uitvoeringsbesluit Wtza onder deze (te) strenge regel zullen vallen!

\section{Conclusie}

De Wtza verbiedt het 'one tier'-bestuursmodel voor bepaalde zorgaanbieders terwijl het WBTR dit bestuursmodel juist voor elke Boek 2 BW-rechtspersoon wettelijk faciliteert. Een (nadere) uitleg voor deze keuze had in de memorie van toelichting van de Wtza niet misstaan.

Het (concept-)Uitvoeringsbesluit Wtza wijkt af van het in het WBTR neergelegde governancemodel. Het is bij bepaalde zorgaanbieders verboden voor leden van de interne toezichthouder (en hun directe verwanten en aanverwanten) om aandelen in de betrokken instelling te houden. De motivering hiervoor acht ik niet steekhoudend en consequent. Uit de bewoordingen van de nota van toelichting bij het (concept-)Uitvoeringsbesluit Wtza maak ik op dat daarin de interne toezichthouder als 'tegenmacht' wordt gezien, die ten behoeve van het maatschappelijk belang en het belang van de cliënt de strijd met het bestuur zou moeten aangaan. Dit vind ik merkwaardig, omdat het bestuur en de RvT juist zo veel mogelijk - ieder vanuit zijn eigen taakstelling - in het belang van de zorginstelling en de daaraan verbonden onderneming of organisatie zouden moeten samenwerken. 
Voorts acht ik de in dit (concept)besluit neergelegde grens van 10 respectievelijk 25 zorgverleners voor de verplichting van Wtza-vergunningplichtige zorginstellingen om een onafhankelijke driehoofdige interne toezichthouder in te stellen veel te laag. Een grens van 50 zorgverleners zou veel realistischer en werkbaarder zijn.

Het Kader goed bestuur schuurt bij twee thema's voor de interne toezichthouder met bestaande en/of voorgenomen wet- en regelgeving. Dit betreft (1) de richting van het toezicht van de RvC/RvT: 'het maatschappelijk belang dienen over de grenzen van de eigen zorgorganisatie' en de leidende rol die de interne toezichthouder daarbij kennelijk zou moeten nemen, en (2) de (te) strikte onafhankelijkheidseisen voor alle (!) commissarissen van een zorginstelling. Deze thema's zijn ook niet goed uitvoerbaar. Mijn conclusie is dan ook dat dit nieuwe Kader goed bestuur bij een aantal thema's voor intern toezicht uit de bocht vliegt.

Daarbij geldt het adagium 'schoenmaker(s), blijf bij je leest!'

Leden van de $\mathrm{RvC} / \mathrm{RvT}$ moeten niet op de stoel van bestuurders gaan zitten en niet gedwongen worden ook het maatschappelijk belang over de grenzen van hun eigen organisatie te dienen. $\mathrm{Zij}$ moeten alleen het belang van de rechtspersoon en de daaraan verbonden onderneming of organisatie dienen. Onlosmakelijk onderdeel van dit belang is overigens de maatschappelijke doelstelling van de zorginstelling om cliënten van hun zorgorganisatie goede zorg te bieden.

De IGJ en de NZa moeten niet treden buiten het externe toezicht waarvoor zij zijn ingesteld. Dit toezicht moet er respectievelijk op zien dat zorgverleners hun patiënten/cliënten goede en veilige zorg verlenen en dat deze zorg betaalbaar, transparant en toegankelijk is en blijft. In die gevallen dat (een van) deze doelstellingen in gevaar (komt) komen door gebreken in het bestuur en/of toezicht van zorgorganisaties mogen de betrokken externe toezichthouders ingrijpen. De bestaande en komende wetgeving bieden daarvoor de nodige handvatten en bevoegdheden. De meldplicht in het (concept-) Uitvoeringsbesluit Wtza brengt nieuwe zorgaanbieders tijdig in beeld bij de IGJ en de vergunningplicht biedt de mogelijkheid om onder meer te toetsen of kwalitatief goede zorg zal worden en wordt verleend, en of sprake zal zijn van een zorgvuldige en transparante bedrijfsvoering. Bij de mijns inziens te ver doorgeschoten eisen op het gebied van de Governance-structuur en met name de taak en de onafhankelijkheid van (de leden van) de interne toezichthouder, heb ik hiervoor de nodige vraagtekens gezet.

Preventief optreden ten behoeve van de doelstellingen van de Wtza en andere zorgwetten door het stellen van een helder en uitvoerbaar Kader goed bestuur is uiteraard ook gewenst. Maar alleen als dat kader gebaseerd is op reeds van kracht zijnde wet- en regelgeving en/of op algemene, breed aanvaarde normen van het veld zelf! De externe toezichthouder ziet toe op normen en regelgeving van het veld. Het is niet aan de IGJ en de NZa om een eigen nadere, nogal verreikende normering - zelfs niet op basis van uitleg van de Governancecode Zorg 2017 aan zorginstellingen op te leggen. De uitleg van de principes van de Code zijn niet 
aan de IGJ of de NZa, maar aan de brancheorganisaties, de door hen ingestelde Governancecommissie Gezondheidszorg en uiteindelijk aan de rechter. 